\title{
Impact of Financial Inclusion on Income Generation and Savings in Mountain Regions: A Case Study of Rural Households of Uttarakhand
}

\author{
Prashant Kandari $^{1} \cdot$ Kusum Dobriyal $^{2 *}$ - Uma Bahuguna ${ }^{3}$ \\ ${ }^{1}$ Department of Economics, H N B Garhwal University (A Central University) Srinagar Garhwal-246174 \\ ${ }^{2}$ Department of Sanskrit, HNB BGarhwal University Campus, Pauri Garhwal- 246001 \\ ${ }^{3}$ Department of Sociology, H N B Garhwal University (A Central University) Srinagar Garhwal-246174 \\ *Corresponding Author Email: kusumdobriyal62@rediffmail.com
}

Received: 04.12.2020; Revised: 30.12.2020; Accepted: 20.03.2021

(C)Society for Himalayan Action Research and Development

\begin{abstract}
The major drive for financial inclusion started in the country mainly from year 2014 after the launch of Jan Dhan Yojana which focused mainly towards empowering dwellers of resource deprived and underdeveloped regions. Economic empowerment of such deprived sections is possible only when they are provided with ample opportunities for income generation in various economic activities. The prominent aim of financial inclusion is to facilitate residents of such deprived regions by reaching out to them and delivering them facilities so that they could identify and work on their capabilities to generate employment and income earning opportunities. The economically deprived and vulnerable population, through it, could be secured, from falling in the trap of poor informal level activities. These low-level informal activities are not suitable for them and for their overall development in the long run. Financial inclusion thus helps them in getting out of the poverty trap and hence acts as one of the important facility or an instrument which could help in a larger achievement of the goal of the development of residents of such deprived regions. Keeping these aspects in consideration the present study aims to understand the impact of financial inclusion on two important variables i.e. income generation and enhancement of savings among the residents of Mountain regions of the state which also represents the deprived and underdeveloped regions. The study was conducted in three mountain districts of the state and the results of the study shows that financial inclusion has helped in income generation in these regions but the impact of it has been different among different caste categories. Further the study shows that financial inclusion worked to enhance the income generation with larger benefits to households having higher levels of income. The study also depicts the positive impact of financial inclusion on savings but with noticeable variations in its impact on different caste groups.
\end{abstract}

Key words: Financial inclusion $\bullet$ Deprivation $\bullet$ Mountain region $\bullet$ Income generation $\bullet$ Savings

\section{Introduction}

'Area Deprivation' reflects towards the factors which leads to the underdevelopment of a region and which traps a region in the vicious circle of underdevelopment. The mountain rural regions of Uttarakhand absorb the same aspect of 'Area Deprivation'. The existence of underdevelopment, poverty and lack of income and employment opportunities arising out of 'Area Deprivation' has resulted in both economic and social deprivation of the residents of such regions and the larger impact of it is on the vulnerable section of population such as lower caste groups or the women of these regions. Different Government schemes and programmes were launched for development of mountain rural regions of Uttarakhand based on issue-based approach.

Financial institutions in mountain rural regions were once largely a medium for sending and receiving of remittances send back by the migrants or to avail social security benefits. The trend of migration from these deprived regions has been continuous and has been so prominent that Uttarakhand economy because of it was termed as "Money order economy'. Among other parameters which indicates poor infrastructure and underdevelopment of these regions the status of financial inclusion is also concerning in these regions of the state. Kandari (2020) in his study of 
analyzing the level of financial inclusion in hill rural region of Uttarakhand states that financial inclusion index (FII) of households of hill rural regions of Uttarakhand is lower than the FII of all India rural households suggesting the relatively higher level of financial exclusion among these hill rural regions of the state.In the present context when the area deprivation of these regions has eventually worked towards continuous degradation of these regions pushing them downwards the process of underdevelopment the role of financial institution has to be reworked both from the supply side and demand side. The new approach of working of financial inclusion is utmost important for the development of these regions.

Goldsmith,1969 \& Fry (1997) has accepted the positive relationship between financial inclusion and economic development of a region and hence they consider financial inclusion as one of a major policyinititiave for regional development. Committee on Financial Inclusion which waschaired by Rangarajan, (2008) has defined financial inclusion as the process of ensuring access to financial services and timely delivery of adequate credit as needed by vulnerable groups such as weaker sections and low-income groups at an affordable cost". Sarma (2008), states that increase in financial inclusion results signifies the inclusive and easy accessibility, availability, and usage of formal financial system by all parts of groups of an economy.Dasgupta (2009) stated financial inclusion as a remedy of financial exclusion and defined it as a "process of making formal financial services accessible and affordable to all. Financial services do not mean the provision of credit alone, but the provision of all other services, especially savings, insurance and remittance facilities". Chakraborty (2011) states that "Financial inclusion is the process of ensuring access to appropriate financial products and services needed by all sections of society including vulnerable groups such as weaker sections and low-income groups at an affordable cost in a fair and transparent manner by mainstream institutional players." Majumdar \& Gupta, (2013) considers financial inclusion on the one hand as process of bringing entire population or at least one member of every household under the umbrella of banking and financial services and on the other as process to make the population capable so that they could effectively opt the financial services for their individual or mutual benefits. Swamy (2014) explains that financial inclusion is a process to bring together the financial institutions and diverse population, which has several resulting benefits through this association. World Bank (2014) suggest that financial inclusion enhances the accessibility of all kinds of financial services to all the sections of population representing all economic and social groups and that too without any discrimination.

As per RBI (2012) a more focused and structured approach towards financial inclusion has been followed since the year 2005 when Reserve Bank of India decided to implement policies to promote financial inclusion and urged the banking system to focus on this goal. Although several schemes and policies were implemented for enhancing the outreach of financial inclusion in the country but the major initiative was taken in August, 2014 when Pradhan Mantri Jan Dhan Yojana (PMJDY)was launched. The policy targeted to expand the availability of banking services to every unbanked household thus securing every unsecure household, funding every unfunded household and at large to targeting the unserved and underserved regions of the country. For attaining it in highly remote and adversely located region and to outreach the accessibility of financial services to the end users the services of intermediaries such as Business Correspondents (BC's) were availed. Further a step ahead towards financial inclusion was undertaken with the increase in government drive to enhance the use of digital platforms for transactions thus achieving the goal of cashless economy. To achieve the digitalization of the financial services and transactions the NPCI introduced a payment application for mobile phones which was termed as Bharat Interface for Money (BHIM). Further to achieve large financial inclusion three very affordable social security schemes which are Atal Pension Yojana, Pradhan Mantri Jeevan Jyoti 
yojana and Pradhan Mantri Suraksha Bima Yojana were launched and were made accessible to those individuals which are holding bank or post office accounts.

\section{Literature Review}

The World Bank (2014) suggests that financial inclusion through enhancing the bank account ownership with the support of leveraging the access and availability of the financial services has also helped in social inclusion. The social inclusion has helped vulnerable population groups such as women, low-income group households, rural residents through increasing their participation in usual financial activities like saving, borrowing and insurance. Demirgüç-Kunt et al. $(2015,2018)$ stated that the financial inclusion helps in attaining more inclusive growth. He further explains financial inclusion with as increase in access to finance can enable beneficiaries to enhance their long run participation in investment activities, could

Help in optimum allocation of productive resources. This will further assist them in reducing cost of capital, will act as buffer for them to observe the short-term economic shocks, will help the beneficiaries to keep them away from informal sources of credit and help them in effective management of finances.

Financial inclusion is critically significant for the overall economic development, mainly of the underdeveloped regions. Beck etal. (2007) explains that the increase in ease to access to financial services helps and motivates the economically deprived and low-income groups to have savings with much security which helps them in adverse economic conditions/shocks and thus reduces their dependences on groups which exploits them in those adverse time period.

Banerjee and Newman (1993) have explained that increase in access to finance helps the individuals and households to increase their productivity thus providing them an opportunity to come out of the poverty trap. Beck, Demirguc-Kunt and Peria (2007) in their study concluded that the access to financial services allows low-income groups to save money safely, prevents holding of economic power with a few individuals and alleviate the risk that poor people face as a result of economic shocks. Honohan (2007) tested the significance of his financial access indicator in reducing income equality. His study results show that higher financial access significantly reduces income inequality as measured by the Gini coefficient. Mandira Sarma and Jesim Paise (2008) suggest that the issue of financial inclusion is a development policy priority in many countries. Among socio-economic factors, as expected, income is positively associated with the level of financial inclusion.

Levine, (1998) and Beck, Demirguc-Kunt and Levine (2007) have noticed a positive effect of finance on poverty reduction. Economies with higher levels of financial development experience faster reduction of poverty. Jabir et al. (2017) explained the positive impact of financial inclusion on reduction of poverty mainly among the low-income household in sub-Saharan Africa. In their study they concluded that financial inclusion reduced the level of poverty in subSaharan Africa to a large extent through providing net wealth and larger welfare benefits to the poor. Salazar-Cantú et al. (2015) studied the effect of financial inclusion on inequality in income distribution in Mexico. The study shows that initially higher financial inclusion led to greater income inequality, but later it reduces the income inequality significantly with its expansion in the country.

Burgess and Pande (2005)explained that the stateled bank branch expansions has helped in reducing rural poverty through delivering banking services in unbanked regions. This was made possible through increase in access to formal sector credit provision and saving opportunities. Arputhamani (2013) while examining the role of financial inclusion in economic empowerment of women in Tamil Nadu revealed that there is a push up in the level of income of the women after financial inclusion drive and financial inclusion through SHG. Maheshwari (2015) studied the level of financial literacy and financial inclusion among the rural women and concluded that 
implementation of financial inclusion drive has led to an increase in socio-economic status of women in these regions.

\section{Research Methodology}

Uttarakhand comprises of 10 mountain districts while other three are designated as plain area districts. The present study was limited to the mountain rural areas of Uttarakhand state for which a sample of three hill districts of the state was selected. The sample districts for the study were Pauri Garhwal, Tehri Garhwal and Chamoli district, comprising 85 percent of rural area. Pauri Garhwal is largest district and has 15 development blocks, Chamoli has 9 development blocks while Rudraprayag districts holds 3 development blocks. Stratified sampling method was utilized to randomly selected 13 development blocks from a total of 27 development blocks. A total of 78 villages were randomly selected from the study and further a sample of 780 households was selected randomly in a manner that all different groups (Based on income status, religion, caste) were included in it. From 780 households a total of 2073 Individuals of age group of 15 years and above age were studied. Due to non-normality of data non-parametric test were utilized for the study.

\section{Objectives of the study}

Following were the objectives of the study:

(i) To study the impact of financial inclusion in enhancing income generation in the mountain rural regions of Uttarakhand

(ii) To study the impact of financial inclusion in promoting savings in the mountain rural regions of Uttarakhand

(iii) To study the variations in the impact of financial inclusion across different socio-economic groups

\section{Results and Discussions}

\section{Socio-economic profile of the households and individuals}

The demographic profile of the households and individuals indicates the inclusion of all socioeconomic categories in the study.

Table No: 1 Demographic profile of the hill rural household

\begin{tabular}{|c|c|c|c|c|c|}
\hline $\begin{array}{l}\text { Demographic } \\
\text { profile }\end{array}$ & Variable & $\begin{array}{l}\text { Frequency } \\
\text { (Households) }\end{array}$ & Percent & $\begin{array}{l}\text { Frequency } \\
\text { (Individuals) }\end{array}$ & Percent \\
\hline \multirow{5}{*}{ Caste } & Gen & 479 & 61.4 & 1241 & 59.9 \\
\hline & OBC & 17 & 2.2 & 46 & 2.2 \\
\hline & $\mathrm{SC}$ & 252 & 32.3 & 710 & 34.2 \\
\hline & ST & 32 & 4.1 & 76 & 3.7 \\
\hline & Male & -- & -- & 998 & 48.1 \\
\hline \multirow[t]{2}{*}{ Gender } & Female & -- & -- & 1075 & 51.9 \\
\hline & Antodaya & 20 & 2.6 & 44 & 2.1 \\
\hline \multirow[t]{4}{*}{ Income Status } & BPL & 407 & 52.2 & 1158 & 55.9 \\
\hline & APL & 353 & 45.3 & 871 & 42.0 \\
\hline & $15-24$ & -- & -- & 390 & 18.8 \\
\hline & $25-34$ & -- & -- & 383 & 18.5 \\
\hline \multirow[t]{3}{*}{ Age Groups } & $35-44$ & -- & -- & 363 & 17.5 \\
\hline & $45-54$ & -- & -- & 399 & 19.2 \\
\hline & 55 and above & -- & -- & 538 & 26.0 \\
\hline
\end{tabular}

Source: ICSSR-IMPRESS-R.P., Primary Survey 2019-20 


\section{Financial inclusion and income generation}

To test the impact of financial inclusion on income generation following null hypothesis was tested.

Null Hypothesis: Distribution of level of financial inclusion is same in the two groups i.e. among the one group which accept that financial inclusion has lead to greater income generation in the

\begin{tabular}{lllll}
\hline Ranks & \multicolumn{1}{c}{$\begin{array}{c}\text { Response related with } \\
\text { Increase_in_income_generation }\end{array}$} & N & Mean Rank & Sum of Ranks \\
& Yes & 349 & 452.12 & 157789.50 \\
\hline FII_household & 431 & 340.60 & 146800.50 \\
& No & 780 & & \\
& Total & & \\
\hline
\end{tabular}

mountain rural regions and another group, which rejects it and states that financial inclusion has failed to enhance income generation in the mountain rural regions of Uttarakhand. The results of the test are as follows:

\begin{tabular}{ll}
\hline Test Statistics $^{\mathbf{a}}$ & \\
\hline & FII_household \\
Mann-Whitney U & 53704.500 \\
Wilcoxon W & 146800.500 \\
Z & -7.179 \\
Asymp. Sig. (2-tailed) & .000 \\
a. Grouping Variable: Increase_in_income_generation
\end{tabular}

The $\mathrm{p}$ value is .000 which is less than 0.05 . We therefore have significant evidence to reject the null hypothesis that the distribution of financial inclusionis not similar in the two groups. Thus the result of the test leads us to conclude that the numerical difference between the mean ranks of financial inclusion among the two categories of response of households is significant. This indicates that financial inclusion is helping the households in greater income generation in these regions of the state.

To test whether this increase in income through financial inclusion is inclusive (equal for all caste categories) we have tested the response across different caste groups. The results of the study are show in Table 2.

The chi-square test confirms that there is association between income generation and different caste groups in these regions. The test result indicates that financial inclusion has helped in relatively more income generation among the General caste category individuals than the other caste groups. This indicates the social exclusion not in case of financial inclusion but in terms of realization of its positive impact which further indicates towards the ineffective usage of financial instruments.

The study has further examined the distribution of the response (for question that financial inclusion has helped in income generation) on the basis of income category of the individuals. The results of the study are shown in Table 3. 
Table 2: Distribution of response on the basis of caste category

\begin{tabular}{|c|c|c|c|c|c|}
\hline \multicolumn{6}{|c|}{ Increase_in_income_generation } \\
\hline & & & \multicolumn{2}{|c|}{$\begin{array}{c}\text { Response related to } \\
\text { Increase_in_income_generation }\end{array}$} & \multirow[t]{2}{*}{ Total } \\
\hline & & & Yes & No & \\
\hline \multirow{8}{*}{$\begin{array}{l}\text { Caste } \\
\text { category of } \\
\text { households }\end{array}$} & \multirow{2}{*}{ Gen } & Count & 264 & 215 & 479 \\
\hline & & $\%$ within Caste_1 & $55.1 \%$ & $44.9 \%$ & $100.0 \%$ \\
\hline & \multirow{2}{*}{$\mathrm{OBC}$} & Count & 6 & 11 & 17 \\
\hline & & $\%$ within Caste_1 & $35.3 \%$ & $64.7 \%$ & $100.0 \%$ \\
\hline & \multirow{2}{*}{$\mathrm{SC}$} & Count & 69 & 183 & 252 \\
\hline & & $\%$ within Caste_1 & $27.4 \%$ & $72.6 \%$ & $100.0 \%$ \\
\hline & \multirow{2}{*}{ ST } & Count & 10 & 22 & 32 \\
\hline & & $\%$ within Caste_1 & $31.2 \%$ & $68.8 \%$ & $100.0 \%$ \\
\hline \multirow{2}{*}{ Total } & & Count & 349 & 431 & 780 \\
\hline & & $\%$ within Caste_1 & $44.7 \%$ & $55.3 \%$ & $100.0 \%$ \\
\hline
\end{tabular}

Source: ICSSR-IMPRESS-R.P., Primary Survey

2019-20

\section{Chi-Square Tests}

\begin{tabular}{llll} 
& Value & Df & Asymp. Sig. (2-sided) \\
\hline Pearson Chi-Square & $54.537^{\mathrm{a}}$ & 3 & .000 \\
Likelihood Ratio & 55.982 & 3 & .000 \\
Linear-by-Linear Association & 51.014 & 1 & .000 \\
N of Valid Cases & 780 & &
\end{tabular}

$\mathrm{N}$ of Valid Cases

780

a. 0 cells $(0.0 \%)$ have expected count less than 5 . The minimum expected count is 7.61.

The test result indicates that the perception among the rural households that financial inclusion has helped in more income generation is largely positive among the individuals belonging to the APL economic status relatively to households belonging to BPL and Antodaya income groups.
This indicates towards lesser extension of benefits of financial inclusion on low income status category households in these regions of the state. This further indicates towards possibility of enhancement of income equality among the rural households in these regions.

Table: 3 Distribution of responses on the basis of Income category

\section{Increase_in_income_generation}

\begin{tabular}{|c|c|c|c|c|c|}
\hline & \multirow[t]{2}{*}{ 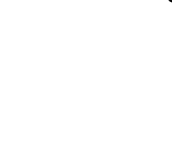 } & & \multicolumn{2}{|c|}{$\begin{array}{c}\text { Response related to } \\
\text { Increase_in_income_generation }\end{array}$} & \multirow[t]{2}{*}{ Total } \\
\hline & & & Yes & No & \\
\hline \multirow{6}{*}{$\begin{array}{l}\text { Income } \\
\text { category } \\
\text { of } \\
\text { househol } \\
\text { ds }\end{array}$} & \multirow{2}{*}{ Antodaya } & Count & 0 & 20 & 20 \\
\hline & & $\%$ within Income_Status & $0.0 \%$ & $100.0 \%$ & $100.0 \%$ \\
\hline & \multirow{2}{*}{ BPL } & Count & 121 & 286 & 407 \\
\hline & & $\%$ within Income_Status & $29.7 \%$ & $70.3 \%$ & $100.0 \%$ \\
\hline & \multirow{2}{*}{ APL } & Count & 228 & 125 & 353 \\
\hline & & $\%$ within Income_Status & $64.6 \%$ & $35.4 \%$ & $100.0 \%$ \\
\hline \multirow{2}{*}{ Total } & & Count & 349 & 431 & 780 \\
\hline & & $\%$ within Income_Status & $44.7 \%$ & $55.3 \%$ & $100.0 \%$ \\
\hline
\end{tabular}


Source: ICSSR-IMPRESS-R.P., Primary Survey 2019-20

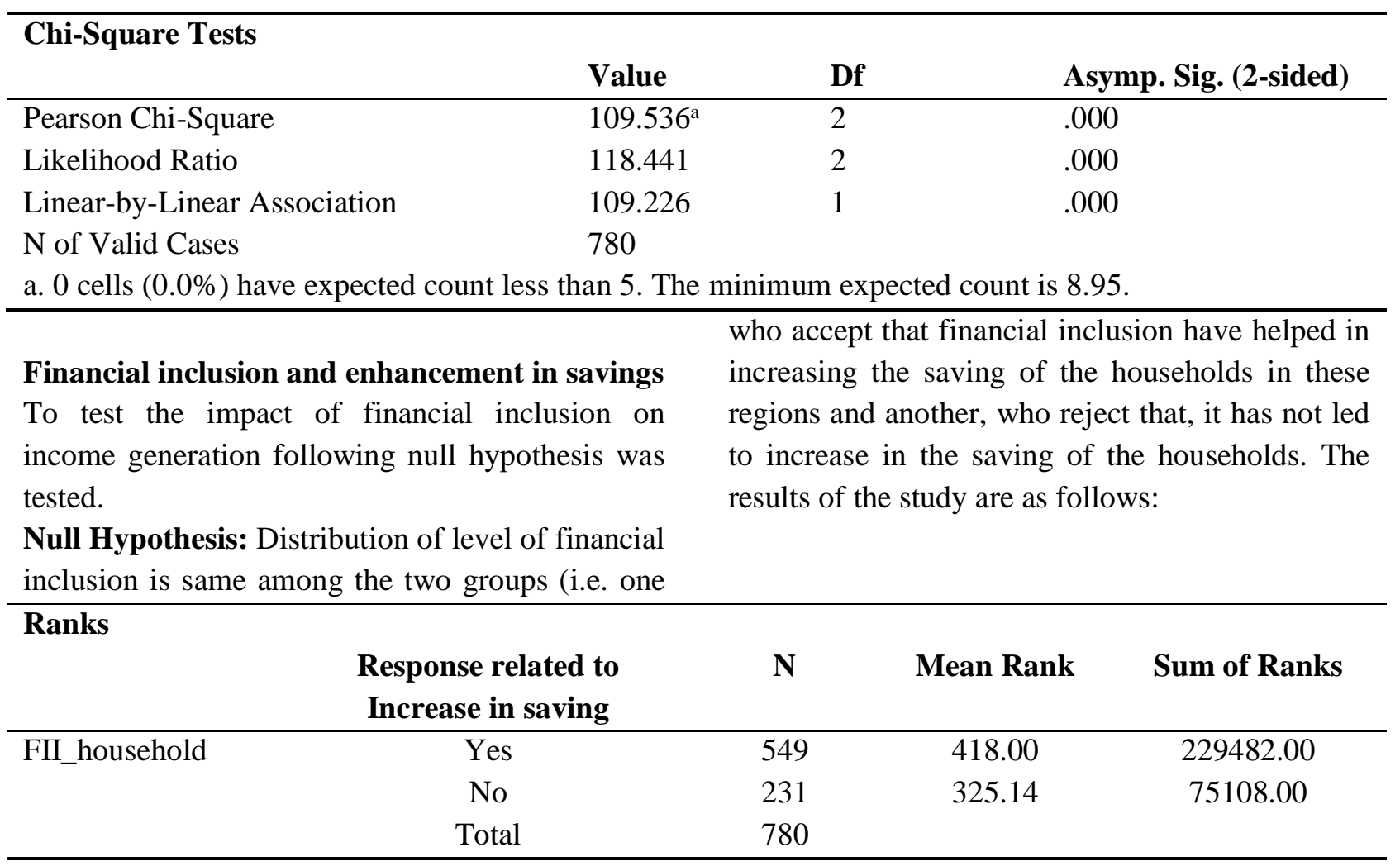

\begin{tabular}{ll}
\hline Test Statistics $^{\mathbf{a}}$ & FII_household \\
& 48312.000 \\
Mann-Whitney U & 75108.000 \\
Wilcoxon W & -5.489 \\
Z & .000 \\
Asymp. Sig. (2-tailed) & a. Grouping Variable: Increase_in_saving \\
\hline
\end{tabular}

The $\mathrm{p}$ value is .000 which is less than 0.05 . We therefore have significant evidence to reject the null hypothesis that the distribution of financial inclusionis not different among the two groups. Thus the result of the test leads us to conclude that the numerical difference between the mean ranks of financial inclusion among the two categories of response of households is significant. This indicates that financial inclusion is helping the households in enhancing the savings among the rural households in mountain regions of the state. To test whether this increase in savings through financial inclusion is inclusive (equal for all caste categories) we have tested the response across different caste groups. The results of the study are shown in Table 4.

Table 4: Distribution of responses on the basis of Caste Status

\begin{tabular}{|c|c|c|c|c|c|}
\hline \multicolumn{3}{|c|}{ Caste Status/Response of households } & \multicolumn{2}{|c|}{$\begin{array}{c}\text { Response related to Increase } \\
\text { in saving }\end{array}$} & \multirow[t]{2}{*}{ Total } \\
\hline & & & Yes & No & \\
\hline Caste & Gen & Count & 382 & 97 & 479 \\
\hline
\end{tabular}




\begin{tabular}{|c|c|c|c|c|c|c|}
\hline \multirow{7}{*}{$\begin{array}{l}\text { category of } \\
\text { households }\end{array}$} & & \multicolumn{2}{|c|}{$\%$ within Caste } & $79.7 \%$ & $20.3 \%$ & $100.0 \%$ \\
\hline & \multirow{2}{*}{$\mathrm{OBC}$} & \multicolumn{2}{|c|}{ Count } & 11 & 6 & 17 \\
\hline & & \multicolumn{2}{|c|}{$\%$ within Caste } & $64.7 \%$ & $35.3 \%$ & $100.0 \%$ \\
\hline & \multirow{2}{*}{$\mathrm{SC}$} & \multicolumn{2}{|c|}{ Count } & 135 & 117 & 252 \\
\hline & & \multicolumn{2}{|c|}{$\%$ within Caste } & $53.6 \%$ & $46.4 \%$ & $100.0 \%$ \\
\hline & ST & \multicolumn{2}{|c|}{ Count } & 21 & 11 & 32 \\
\hline & ונה & \multicolumn{2}{|c|}{$\%$ within Caste } & $65.6 \%$ & $34.4 \%$ & $100.0 \%$ \\
\hline \multirow{2}{*}{\multicolumn{2}{|c|}{ Total }} & \multicolumn{2}{|c|}{ Count } & 549 & 231 & 780 \\
\hline & & \multicolumn{2}{|c|}{$\%$ within Caste } & $70.4 \%$ & $29.6 \%$ & $100.0 \%$ \\
\hline \multicolumn{7}{|c|}{$\begin{array}{l}\text { Source: ICSSR-IMPRESS-R.P., Primary Survey } \\
2019-20\end{array}$} \\
\hline \multicolumn{7}{|c|}{ Chi-Square Tests } \\
\hline & & & Value & df & \multicolumn{2}{|c|}{ Asymp. Sig. (2-sided) } \\
\hline \multicolumn{2}{|c|}{ Pearson Chi-Square } & & $54.939^{\mathrm{a}}$ & 3 & \multicolumn{2}{|c|}{.000} \\
\hline \multicolumn{2}{|c|}{ Likelihood Ratio } & & 53.798 & 3 & \multicolumn{2}{|c|}{.000} \\
\hline \multicolumn{3}{|c|}{ Linear-by-Linear Association } & 47.331 & 1 & \multicolumn{2}{|c|}{.000} \\
\hline \multicolumn{3}{|c|}{$\mathrm{N}$ of Valid Cases } & 780 & & & \\
\hline
\end{tabular}

The rests result indicates that the positive impact of financial inclusion on increase in savings has been relatively more among the General caste category individuals than in case of other caste category individuals.

To test whether this impact of financial inclusion is equal among all income categories individual we have distributed the response of the individuals on the basis of their responses to the question that whether financial inclusion has helped them in increasing their savings. The results of the study are in Table 5.

Table 5: Distribution of responses on the basis of Income Status

\begin{tabular}{|c|c|c|c|c|c|}
\hline \multirow{2}{*}{\multicolumn{3}{|c|}{ Income Status/Response of households }} & \multirow{2}{*}{\multicolumn{2}{|c|}{$\begin{array}{c}\text { Response related to } \\
\text { Increase in saving }\end{array}$}} & Total \\
\hline & & & & & \\
\hline \multirow{6}{*}{$\begin{array}{l}\text { Income category of } \\
\text { households }\end{array}$} & \multirow{2}{*}{ Antodaya } & Count & 7 & 13 & 20 \\
\hline & & $\%$ within Income_Status & $35.0 \%$ & $65.0 \%$ & $100.0 \%$ \\
\hline & \multirow{2}{*}{ BPL } & Count & 250 & 157 & 407 \\
\hline & & $\%$ within Income_Status & $61.4 \%$ & $38.6 \%$ & $100.0 \%$ \\
\hline & \multirow{2}{*}{ APL } & Count & 292 & 61 & 353 \\
\hline & & $\%$ within Income_Status & $82.7 \%$ & $17.3 \%$ & $100.0 \%$ \\
\hline \multirow{2}{*}{ Total } & & Count & 549 & 231 & 780 \\
\hline & & $\%$ within Income_Status & $70.4 \%$ & $29.6 \%$ & $100.0 \%$ \\
\hline
\end{tabular}

Source: ICSSR-IMPRESS-R.P., Primary Survey

2019-20

The test result indicates that financial inclusion has largely helped the APL families in enhancing their savings relatively to that of the BPL and

Antodaya households. This indicates towards exclusion of low income status households from 
this positive impact of financial inclusion in these mountain rural regions of the state.

\begin{tabular}{llll}
\hline Chi-Square Tests & Value & df & Asymp. Sig. (2-sided) \\
\hline Pearson Chi-Square & $53.453^{\mathrm{a}}$ & 2 & .000 \\
Likelihood Ratio & 54.154 & 2 & .000 \\
Linear-by-Linear Association & 53.184 & 1 & .000 \\
N of Valid Cases & 780 & &
\end{tabular}

a. 0 cells $(0.0 \%)$ have expected count less than 5 . The minimum expected count is 5.92 .

\section{Conclusion}

The results of the study clearly indicate towards the importance of financial inclusion for these underdeveloped mountain rural regions of the state. The financial inclusion has not only helped in enhancing income generation but also has succeeded in increasing savings among the households of these regions. The success of any policy is judged from the mere nature of its inclusiveness not only in case of its implementation but also in respect of its impact on the overall community covering all sections of population. The present study shows that financial inclusion has been inclusive in its implementation approach but in case of its impact the results are not so positive. The concerning issue that arises from the results of the study is that the two positive impacts of financial inclusion i.e. enhancement in income generation and savings has not been socially inclusive, the results of the study shows that financial inclusion has not equally helped all caste group in increasing their income and savings. Further these positive impacts of financial inclusion have not also been inclusive on economic basis. The financial inclusion has largely helped the APL households in enhancing income generation and savings relatively to that of BPL and lower income category households which could enhance income inequality among the rural households in these regions in long run. The study thus help was to conclude that the development of such underdeveloped and deprived regions could only be attained when all the segments of population including the vulnerable groups based on caste or gender or income status are equally brought under the ambit of such schemes with further ensuring

the positive impact of such policies on them. The wider positive impact across the different segments of population could be attained through enhancing financial literacy and making them aware about the better usage of available financial instruments.

\section{Acknowledgement}

First Author thankfully acknowledges the financial support rendered by Indian Council of Social Science Research, New Delhi under IMPRESS Scheme, MHRD, GoI

\section{References}

Arputhamani J (2013). Economic Upliftment of Women through Financial Inclusion: A study with reference to Virudhunagar district of Tamil Nadu. Ph.D. Thesis

Banerjee AV \& Newman AF (1993). Occupational choice and the process of development. The J Po. Eco. 101(2), 274-298

Beck T A, Demirguc-Kunt and M S Peria (2007). "Reaching Out: Access To and Use of Banking Services across Countries," Journal of Financial Economics, Vol 85, pp 234-66.

Beck T, Demirgüç-Kunt A and Levine R (2007). "Finance, inequality and the poor", $J$ Eco. Grw., 12(1), 27-49.

Burgess R Pande R (2005) Do rural banks matter? Evidence from the Indian social banking experiment. Am Econ Rev 95(3):780-795 
Charkravarty SR \& Pal R (2011). Measuring financial inclusion: an axiomatic approach. IGIDR,WP 2010(3).

Dagupta, Rajaram (2009). Economics and Political weekly, June 27, 2009 vol xliv nos $26 \& 27$

Demirgüç-Kunt A, Klapper L, Singer D, Ansar S, Hess J (2018). The Global Findex Database 2017: measuring financial inclusion and the fintech revolution. World Bank Group, Washington, DC.

Demirgüç-Kunt A, Klapper L, Singer D, Van OP (2015). The Global Findex Database 2014: measuring financial inclusion around the world. Policy Research Working Paper 7255. World Bank Group, Washington, DC.

Fry M J (1997). "In favour of financial liberalization". The Eco. J.107(442): 754770.

Goldsmith RW (1969). Financial Structure and Development. Yale University Press. New Haven.

Honohan P (2007). Cross country variation in household access to financial services. Paper prepared for the World Bank Conference on Access to Finance. March 15-16.

Jabir MI, Mensah L, Gyeke-Dako A (2017). Financial inclusion and poverty reduction in sub-Saharan Africa. Afr Fin J 19: pp1-22

Kandari (2020), Status of Financial Inclusion in Hilly Rural Areas of Uttarakhand: A Comparative Study of Pauri, Chamoli And Rudraprayag District, J. Mountain Res, 15, (2020), 21-33

Levine R (1998). "The Legal Environment, Banks, and Long-Run Economic Growth". $J$. Money, Credit, Bank. 30. Pp. 596-613.

Maheshwari M (2015). A study on financial inclusion among rural women in tirunelveli districtll. Ph.D. Thesis. Retrieved from http://hdl.handle.net/10603/131044.

Majumdar C \& Gupta G (2013). Financial Inclusion in Hooghly. The Ec. Pol.Wee.48 (21): 55-60.

Mandira Sarma and Jesim Paise (2008). Financial Inclusion and Development: A Cross Country
Analysis. Indian Cou. Res. Inter. Eco.Rel.. 128.

Rangarajan Committee (2008). "Report of the committee on financial inclusion". Government of India.

RBI (2012). Retrieved from weblink: https://www.rbi.org.in/scripts/BS SpeechesV iew.aspx?Id=749; Financial Inclusion Issues in Measurement and Analysis (Keynote Address by Dr. K. C. Chakrabarty, Deputy Governor, Reserve Bank of India at the BIS-BNM Workshop on Financial Inclusion Indicators at Kuala Lumpur on November 5, 2012

Salazar-Cantú J, Jaramillo-Garza J, Rosa BÁ (2015). Financial inclusion and income inequality in Mexican Municipalities. Open $J$ Soc Sci 3:29-43

Sarma M (2008). "Index of financial inclusion". ICRIER Working paper no. 215.

Swamy V (2014). "Financial inclusion, gender dimension, and economic impact on poor households". Wor. Dev.. 56, Pp. 1-15.

World Bank (2014). Global financial development report 2014: financial inclusion. World Bank Group, Washington. DC.

World Bank (2014). Global financial development report 2014: Financial Inclusion. Washington, DC.

$$
* * * * * * *
$$

